\title{
CITIZEN OF THE POLIS AND CITIZEN OF THE WORLD: HANNAH ARENDT ON HUMAN AND CIVIC RIGHTS
}

\author{
Letizia Konderak ${ }^{1 *}$
}

${ }^{1}$ Humanist Department, University of Aldo Moro, Bari, Italy
* Correspondent author: Letizia Konderak - letizia.konderak@ uniba.it

Received: 9.9. 2020; Accepted:28.11.2020; Published: 20.12.2020

DOI: https://doi.org/10.46473/WCSAJ27240606/20-12-2020-0022

Category: Research paper

\begin{abstract}
Arendt's reflections on the critical issues of Human Rights still hold relevance after seventy years: the news reports the baffling condition of immigrants, refugees, sans papier and people trying to cross borders towards a better life daily. These people are still forced to live outside the law as the displaced persons have been since the two World wars. Arendt's claim on the emptiness of human rights - which are guaranteed only when they are citizens' rights - has been discussed by French philosophers like Rancière and Balibar. These philosophers affirms the effectiveness of human rights for political action: Rancière states that human rights open the political space for the inclusion of the excluded; for Balibar human rights are both extensively and intensively universal, that is, they exclude exclusion. Contrastingly, the Italian jurist Agamben radicalizes Arendt's thesis: human rights are the means for an original violence towards men, because their exclusive inclusion pins them to bare life. This paper aims to discuss these reading on the matter of human rights, focusing on Arendt's constitutional politics. Her discussion on the birth of the United States reveals that she considered the horizontal and vertical multiplication of power institutions as the core solution against both political exclusion and institutional weakening. Universal institutions do not exclude local ones, but they strengthen each other. Arendt's idea offers a way to rethink humanity and universal inclusion, through concrete institutions which make rights effective.
\end{abstract}

Keywords: Arendt, human rights, civic rights

"Who is the subject of the rights of man?" (Rancière, 2004) The answer to this question might seem tautological: the subject of the rights of man is just man. Nevertheless, sorrows bothering refugees, displaced persons and immigrants since the end of the First World War to nowadays point to a much more entangled situation, since human rights of these people are far from being guaranteed. Since 1919, the production of stateless persons became a steady feature of the main political events: "the refugees and the stateless have attached themselves 
like a curse to all the newly established states on earth which were created in the image of the nation-state" (Arendt 1976, 290) ${ }^{1 .}$

This contribution aims to discuss Arendt's perspective on the connection between human and civic rights as well as the perplexities of human rights; it will also provide an overview on the Italian and French debate on human rights; finally, it will analyse Arendt's idea of new international institutions, and their articulation with local and state entities: the scope is showing that Arendt's reading of the American Revolution shed light on a structure of power which allows the integration of international institutions and civic activities through plural levels of power.

\section{Arendt: the right to have rights}

Arendt's analysis of the stateless and minorities' condition between the two World Wars in The Origins of Totalitarianism (Arendt, 1976, 267-302) is the starting point of this debate. The twilight world which Arendt described joins ours for the widespread sense of superfluousness affecting human beings: economic crisis, unemployment, overpopulation, and, at that time, the dissolution of some supranational political entities (such as the AustroHungarian empire) and civil wars released a mass of lost people, who did not fit in the new worldly structures anymore: they were the stateless and minorities, "the scum of the earth" (267).

Minorities were national groups who were forced together with others by the artificial construction of national States in eastern Europe, while their ethnic belonging implied a minor juridical status: it was the condition of Slovaks in Czechoslovakia, of Croats and Slovenes in Yugoslavia (270). The Treaty of Versailles of 1919 created new political entities bonding together several ethnic groups, but only one of them was the state-nation; others were just minorities, deprived of full juridical status.

According to Arendt, the political strategy of the Treaty of Peace was an apodictic refutation of the principles of the European National State system: the assumption which founded the European balance was that every nation - that is, every ethnic group, whose members were defined by their common birth and blood - had a right to self-determination by the means of a juridical State. The principle of "blood and soil" (Blut und Boden) stands still so firmly that in our everyday language nation and State tend to be considered as synonyms, tying them more and more tightly: the positive and juridical institutions are thus mixed with nature and natality ${ }^{2}$.

In Arendt's view, the artificial setting up of new-born States broke down the European political system, because it showed that the right to a nation-State was the privilege of the main political and military ethnic groups. Furthermore, the paradoxes underlining the European political structure was witnessed by the baffling condition of minorities in the new states: due to their national belonging, they were not equal citizens. In Arendt's words (276): the minorities "de jure [...] belonged to some political body even though they needed additional protection in the form of special treaties and guaranties".

\footnotetext{
${ }^{1}$ This rhythmical production of flows of immigrants is confirmed by an interview which Foucault issued in 1979 about the Vietnamese refugees which is significantly entitled "The problem of refugees is an omen of the great migration of the $21^{\text {th }}$ century" Foucault 1994.

2 On this matter, see also Agamben, 2008 pp. 90-95.
} 
This paradox - an actual time bomb for the European system - was even more dramatic for the stateless (Heimatlose, apatrides) who spread steady across Europe because of civil wars (i.e. the Spanish civil war and the Russian Revolution) and of ethnic purges (for example the Armenians). Even if their condition was meant to be a small exception, numbers spoke and still speak differently:

"The decision of the statesmen to solve the problem of statelessness by ignoring it is further revealed by the lack of any reliable statistics on the subject. This much is known, however: while there are one million 'recognized' stateless, there are more than ten million so-called 'de facto' stateless; and whereas the relatively innocuous problem of the 'de jure' stateless occasionally comes up at international conferences, the core of statelessness, which is identical with the refugee question, is simply not mentioned. Worse still, the number of potentially stateless people is continually on the increase" $(1976,279)^{3}$.

People banished from their homeland were unable to find a new home, because of the critical economic conditions and because of ideological reasons: no country was willing to welcome them. Superfluousness (Arendt, 1976, 311) became their daily experience: they were the indésirable (283) of the world. If their homeland had deprived them of their basic rights, no country in the world seemed to assist or give them those rights back. That is the paradox which the stateless revealed, according to Arendt: men which were no more citizens, which were nothing but men, and whose human rights should have granted them a natural and immediate protection, revealed to be deprived of every right, unable to find a juridical shelter.

Before discussing Arendt's analysis of the perplexities of the rights of man, two consequences of the spread of statelessness are to be stressed: first, since these people lived outside the law, their presence all over Europe meant a spread of illegality in the core of civilisation:

Much worse than what statelessness did to the time-honoured and necessary distinctions between nationals and foreigners, and to the sovereign right of states in matters of nationality and expulsion, was the damage suffered by the very structure of legal national institutions when a growing number of residents had to live outside the jurisdiction of these laws and without being protected by any other. The stateless person, without right to residence and without the right to work, had of course constantly to transgress the law. He was liable to jail sentences without ever committing a crime (286).

Second, their awkward condition paradoxically benefited from minor crimes, because a crime inscribed them into the juridical system, gaining them a place in the law (ibid.).

\footnotetext{
${ }^{3}$ The United Nations High Commissioner for Refugees appreciates in 2008 that refugees amount to 65.3 million people, while de facto migrants amount to almost 250 million people in 2017 (DeGooyer et al., 2018, 87).

In a recent article Greblo (2018) deals with the condition of immigrants and stateless, the "border humanity", trying to update Arendt's analysis. He points to the mobility of the borders, which are often located in the middle of the national States (72): immigration reception centres allow immigrants to turn the bond into a place for emancipation and integration (71). However, this condition is a privilege of "regular" immigrants. Sans papiers - illegitimate immigrants without documents - are trapped in outsourced reception centres: borders are placed far from Europe and USA, and immigrants are imprisoned there. Greblo mentions the Nauru and the Manus islands, and Papua New Guinea (76). Europe manages immigration flows on the coasts of Libya and on the border between Turkey and Greece; another famous reception centre is "The Jungle" in Calais (France). Italy drew up a contract with Libya in 2007 to control immigration flows, which was later ratified in 2017 and in 2020; Germany and Turkey drew up the same kind of treaty in 2016.
} 
Finally, Arendt questions the weakness in the very conception of the rights of man, since their declaration in 1789: in her view, the plight of the stateless is rooted in the very foundation of the universal human rights as declared by the French revolutionaries. In Arendt's words: "since the Rights of Man were proclaimed to be 'inalienable', irreducible to and undeducible from other rights or laws, no authority was invoked for their establishment; Man himself was their source as well as their ultimate goal. No special law, moreover, was deemed necessary to protect them because all laws were supposed to rest upon them" (291).

Theoretical and political weaknesses afflicted the 1789 Déclaration: from a conceptual viewpoint, Man, the subject of the inviolable rights and a "completely emancipated [yet] completely isolated being" (ibid.), is also intangible according to Arendt. "Man" is an abstraction which exists nowhere, while real men exist only in the plural and in a concrete political and social body ${ }^{4}$. Consequently, man immediately "disappeared again into a member of a people" (Arendt, 1976, 291), and the struggle for "rights as normative setbacks to sovereignty" (Gündoğdu, 2015, 44) suddenly disappeared into the struggle for the conquer of sovereignty itself: only people in a national State, who had beheaded the king and took his place, could enjoy those inviolable rights. Therefore, only citizens of emancipated ethnic groups - nations who had conquered the State - enjoyed human rights:

'The Rights of Man, after all, had been defined as 'inalienable' because they were supposed to be independent of all governments; but it turned out that the moment human beings lacked their own government and had to fall back upon their minimum rights, no authority was left to protect them and no institution was willing to guarantee them" (Arendt, 1976, 291-2).

Minorities and stateless were not "unfortunate exceptions in a progressively evolving system of human rights" (Gündoğdu 2015, 41), but the keystone where the European political order foundation crumbled down: people who were no more citizens, but bare men, were found to be rightless: "if a human being loses his political status, he should, according to the implications of the inborn and inalienable rights of man, come under exactly the situation for which the declarations of such general rights provided. Actually, the opposite is the case" (Arendt, 1976, 300).

In Arendt's view, stateless revealed that beyond civic rights there is a right to have rights (296), for only belonging "to some kind of organized community" (297) warrants basic human rights. Beyond the revolutionaries' willing, something like a common ground between human rights and racism seems to emerge: both were grounded in bare birth, rather than in any human deed (DeGooyer et al., 92-3).

Benhabib (2003, 185) attributes a constructive meaning to the syntagma "right to have rights", on the assumption that Arendt used the term "right" in two different meanings: while the second time it addresses particular legal rights, the first "right" is a moral claim to the Kantian, universal being which dwells in every man ${ }^{5}$. Contrarily, Arendt's formula about this meta-right addressed the weaknesses of the sovereign nation-state and of international

\footnotetext{
4 "Men, not Man, live on the Earth and inhabit the World" (Arendt, 1990, 175 and 1998, 7). "God has created Man, Men are a human and worldly product, the product of human nature" ("Gott hat den Menschen geschaffen, die Menschen sind ein menschliches, irdisches Produkt, das Produkt der menschlichen Natur“, Arendt, 1993, 9).

5 This interpretation was encouraged by the other article where Arendt mentions the "right to have rights", entitled "There is only One Human Right" (1949), "Es gibt nur ein einziges Menschenrecht" (DeGooyer et al., 2018, 52).
} 
institutions trying to enact human rights, whose failure derived from thinking of human rights as something naturally attached to men ${ }^{6}$.

Last, from a political viewpoint, since the French Revolution transferred sovereignty from the king to the people, and people soon became poor and destitute ${ }^{7}$, the meaning of rights of man shifted again to the rights of the victims. At the same time, since these poor people were sovereign - that is the absolute criterion, the beginning and the end of politics itself - politics became a means for accomplishing public and private wealth and welfare ${ }^{8}$, that is, politics became "political economy" (Arendt, 1998, 29), a bare servant of national supreme interests. Another image standing for this paternalistic idea of politics it that of body politics as a family - according to the etymology of the word "economy" - where the father (despotes) provides cultivation and health for everybody.

Finally, Arendt's provisional answer to the question "who is the subject of the rights of man?" is: a man who exists nowhere - that is, the expelled refugee, abandoned by or fleeing from his homeland - or a poor and deprived man.

\section{Agamben: sovereignty and bare life. The threat of Human Rights}

"The world found nothing sacred in the abstract nakedness of being human" (Arendt, 1976, 299): this Arendt's statement resumes her pessimism about human rights. The Italian philosopher Giorgio Agamben radicalizes Arendt's gloomy judgment about human rights, aiming to a politics beyond human rights.

Agamben's interpretation on Arendt's discussion of human rights is mainly developed in Homo sacer (Agamben, 1998); in this text, in Gündoğdu words,

"waring against the temptation to read the post-45 ascendency of human rights as a sign heralding a post national order, Agamben instead underlines that human rights have been

\footnotetext{
${ }^{6}$ On Arendt's criticism of sovereign and national right of expulsion ibid., p. 26, p. 44, pp. 68-69 and p. 81; for the lack of authority of international institutions see ibid., pp. 30-31; and Arendt 1976, 269-286, 298. Arendt expressed the same idea in a 1943 article: "Before you cast the first stone at us, remember that being a Jew does not give any legal status in this world. If we should start telling the truth that we are nothing but Jews, it would mean that we expose ourselves to the fate of human beings who, unprotected by any specific law or political convention, are nothing but human beings" (Arendt, 2008, 273).

7 "The social question" (Arendt, 1990, 59-114): in Arendt's view the French Revolution transformed "the rights of Man into the rights of Sans-Culottes" (61). Rancière highlights clearly this idea: nobody's rights became the rights of the weak, which needs a paternalistic largesse for joining rights (Rancière, 2004, 298).

${ }^{8}$ Arendt thinks that the idea of politics as a mean to a higher end is one of the most common - yet incorrect and baleful - prejudices about politics ("Politics as a means for a higher end to establish", "Politik als ein Mittel für einen höheren Zweck zu bestimmen”, Arendt, 1993, 36). See also DeGooyer et. Al., 2018, 56-58.

${ }^{9}$ Oikos means the house, while nomos means law: in ancient Greek Oikonomia meant the house management (Arendt, 1998, 28 and 33). "Till body politic is built on the family and it is understood in the image of Family, family tie in its various degrees applies as, on one side, what can connect strangers, and, on the other side, as what allows individual shapes to differ and to distinguish one from each other. In this kind of organization, the original difference is equally effectively erased, while the fundamental equality of all men is destroyed, when Man is what one deals with. The ruin of Politics on both sides rises from the development of body politic on Family" ("Solange man politische Körper auf der Familie aufbaut und im Biden der Familie versteht, gilt Verwandtschaft in ihren Graden als das, einerseits, was die Verschiedensten verbinden kann, und als das, andererseits, wodurch wieder individualen-ähnliche Gebilde sich von- und gegenein- ander absetzen. In dieser Organisationform ist die ursprüngliche Verschiedenheit ebenso wirksam ausgelöscht, wie die essentielle Gleichheit aller Meschen, sofern es sich um den Menschen handelt, zerstört ist. Der Ruin der Politik nach beiden Seiten entstehet aus der Entwicklung politischer Körper aus der Familie”, Arendt, 1993, 10).
} 
inextricably intertwined with the nation-state (and its biopolitical sovereignty) from their early origins in the eighteenth-century declarations. These rights do not work against sovereignty, Agamben contends: they instead reinscribe it in new ways" (Gündoğdu, 2015, 44).

Specifically, Agamben regards at the Declarations of the rights of man10 as a glimpse into the concealed nature of power, that is the deep and inextricable coincidence of biopower and sovereign power $(45)^{11}$. The grim essence of power as biopower consists - and has always consisted, from Agamben's viewpoint - of the arbitrary decision of power over bare life, which means bare life's exposure to sovereign decision over its life and death.

All these terms have a heavy tradition in 20th century political philosophy: first, biopolitics or biopower. First coined by Michel Foucault, the term means a rule or power which targets life itself; according to Agamben,

"Biopower is not a distinctively modern form of power, but is always already implicated in sovereignty. It is the type of power at work not only in modern democracies but also in absolute monarchies. To the extent that sovereign, in its archaic and modern forms, always consists in a decision on life, it is indeed inseparable from biopower" ${ }^{\prime 2}$.

According to Agamben, power is intrinsically biopower, because it addresses bare life. Furthermore, power is sovereign because it decides on life and death of its subjects (Foucault, 1976, 177), and because it "decides in the state of exception" (Agamben, 1998, 11) ${ }^{13}$. This paradoxical prerogative of sovereign power, that is, being at the same time outside and inside the juridical order (Agamben, 1998, 15), founds the political structure itself: the state of exception is the joint between the heterogeneity of politics and life, since in it sovereign power captures life, eventually decides of its life and death or decrees the law in force.

Finally, bare life is the result of the sovereign exception, because it is life itself as captured by power in the "grey zone between law and fact" (Gündoğdu, 2015, 47). In Agamben's view, bare life is neither political, qualified life (the life of the political citizen), nor natural life; some historical examples help to understand this sort of phantom: the inmates in the concentration camps, i.e. "life that does not deserve to live" $(1998,136)$, and the overcomatose people (160). Modern State's assumption of natality and birth as the condition for

\footnotetext{
10 "Biopolitics and the rights of man" (Agamben, 1998, 126-135); according to Agamben, the same logic infests the Habeas Corpus, 1679 (123).

11 "The present inquiry concerns precisely this hidden point of intersection between the juridico-insitutional and the biopolitical models of power. What this work has had to record among its likely conclusions is precisely that the two analyses cannot be separated, and that the inclusion of bare life in the political realm constitutes the original - if concealed - nucleus of sovereign power. It can even be said that the production of a biopolitical body is the original activity of sovereign power. In this sense, biopolitics is at least as old as the sovereign exception" (Agamben, 1998, 6).

12 The distance between Agamben's reading of biopower and Foucault's has been widely analysed, for example in Ojakangas, 2005 and Snoek, 2010. This contribution is not meant to point out at the differences between the two positions. Nevertheless, Foucault dated precisely the birth of Biopolitics in $18^{\text {th }}$ century, - the biological threshold of the modern era, when a new form of power appeared : "Man has remained for millennia what he was for Aristotle: a political animal; modern man is an animal whose life of living being is questioned in his politics" ("L'homme, pendant des millénaires, est resté ce qu'il était pour Aristote: un animal politique; l'homme modern est un animal dans la politique duquel sa vie d'être vivant est en question", Foucault, 1976, 188). On the opposite, Agamben (Agamben, 1998, 3).

${ }^{13}$ Agamben quotes Carl Schmitt definition of sovereignty.
} 
political citizenship witnesses that bare life is becoming the pivot of politics ${ }^{14}$. Last, the Roman juridical figure of Homo sacer, which names Agamben's book itself, is an example of the production of bare life: the term sacred, far from indicating something blessed, too holy to be touched by human hands, was originally the term for a man whose awful crime allows everyone to kill him without committing homicide ${ }^{15}$.

Agamben's aim is clear: the adjective "sacred" ascribed to human rights or to Man is an alarm signal, because it shows that gloom sovereign power impedes over whatever is called sacred. Since - according to Agamben - the sovereign violence lies in its foundation, its nature is rarely revealed; even so, all citizens, all men subjected to power are "potentially homines sacri” (Agamben, 1998, 84).

Bare life captured in sovereign exception is a paradoxical inclusive exclusion (21), which holds life but keeps it out of the political order. With Arendt and beyond her, Agamben argues that the mechanism of sovereignty traces a line between men who are worth being included in the juridical order and men who are not - although one always risks being excluded and exposed to sovereign violence. Specifically, it also defines the border between humanity and inhumanity, since the exclusion from human juridical order implies an exclusion from humanity itself $(7)^{16}$.

Lastly, Agamben's answer to the question about the subject of the rights of man is: all men are such subjects, that is all men are subjected to the sovereign power which rules over their life or death in the state of exception.

\section{Rancière and Balibar: the transformative power of human rights}

While Agamben's reading of the perplexities of the Rights of Man is quite pessimistic, Jacques Rancière and Étienne Balibar still recognize a positive political role to these rights. Their readings could be defined as performative - according to Judith Butler's interpretation (DeGooyer, 2018, 21) or evolutionary (Gündoğdu, 2015, 43), since both think that human rights open a space for political revendication, and thus for an enlargement of political inclusion towards universality.

Rancière recognizes that the current failure of human rights is due to the perplexities highlighted by Arendt's analysis, that is, man actually is the citizen. Furthermore, he states that the weakness of their theoretical foundation leaves room for an instrumental use of human rights. For example, military and political intervention use the façade of humanitarianism to invade poor and victimized peoples' countries:

\footnotetext{
14 "It is only because this declaration (the 1789 Declaration of the Rights of Man and Citizen) inscribed the native element in the heart of any political organization that it can firmly bind the principle of sovereignty to the nation" (Agamben 1998, 123-135 and 2008, 93).

${ }^{15}$ According to the grammarian Festo: "The sacred man is the one whom the people have judged on account of a crime. It is not permitted to sacrifice this man, yet he who kills him will not be condemned for homicide; in the first tribunitian law, according to the plebiscite, in fact, it is noted that if someone kills the one who is sacred according to the plebiscite, it will not be considered homicide'. This is why it is customary for a bad or impure man to be called sacred" (Agamben, 1998, 71). The first version of The Origins of Totalitarianism described the condition of the Stateless as a "constant temptation to murderers", since when a stateless dies "we may not be aware that anybody has been murdered at all if, for practical purposes, he did not exist before" (DeGooyer et al., 2018, 76); the statement was dropped from the revis ed edition (117, note 46).

${ }^{16}$ Elsewhere Agamben defines this mechanism as an "anthropological machine" (Agamben, 2004, 79) which generates human beings both politically and ontologically.
} 
"The Rights of Man turned out to be the rights of the rightless, of the populations hunted out of their homes and land and threatened by ethnical slaughter. They appear more and more the rights of the victims, the rights of those who were unable to enact any rights or even any claim in their name, so that eventually their rights had to be upheld by others, at the cost of shattering the edifice of International Rights, in the name of a new right to "humanitarian interference' - which ultimately boiled down in the right to invasion" (Rancière, 2004, 297298).

Nevertheless, Rancière thinks that Arendt's reading of the Déclaration des droits de l'homme et $d u$ citoyen alludes to just one functioning of theirs, and not to the most effective one. Rancière thinks that the best way to use the rights of man is not recording their inefficacy but verifying them politically. Indeed, all the excluded - women, black people, immigrants - must not only record the gap between the Constitution and reality: instead, they should use this gap for the construction of a dissensus (304) about the legitimacy of exclusion, and the necessity of inclusion:

"The Rights of Man are not the rights of a single subject that would be at once the source and the bearer of the rights and would only use the rights that she or he possesses. If this was the case, indeed, it would be easy to prove, as Arendt does, that such a subject does not exist. But the relation of the subject to his or her rights is a little more complicated and entangled. It enacts through a double negation. The subject of the rights is the subject, or more accurately the process of subjectivization, that bridges the interval between two forms of the existence of those rights. Two forms of existence. First, they are written rights. They are inscriptions of the community as free and equal. As such, they are not only the predicate of a nonexisting being. [...] They are not only an abstract ideal, situated far from the givens of the situation. They are also part of the configuration of the given. What is given is not only a situation of inequality. It is also an inscription, a form of visibility of equality" (302-3).

According to Rancière, Human Rights' scope is certainly not to describe an eternal and essential feature of men; nevertheless, they are effective because excluded men and women can appeal them to question their exclusion and to revendicate inclusion. By this public dissensus, the protesters could both verify the effectivity of the rights of Man, and show "that they had the rights that the constitution denied to them, that they could enact those rights" $(304)^{17}$ : from Rancière's viewpoint, protesting means forcing everyone to recognise one's place in the political body.

Thus, in Rancière's view, human rights are the main political operator to increase inclusion and political participation: Rancière calls this process political subjectivization (304). Furthermore, Rancière states that politics is located in the very border between inclusion and exclusion, that is in staging a dissensus about the extension and comprehension of political names (Ibid.).

Therefore, Rancière recognizes Arendt and Agamben's border between life and politics, between men whose rights are granted because they are citizens and prisoners of a barely natural, "inhuman" condition. However, he thinks that these determination - citizen and bare

\footnotetext{
${ }^{17}$ Rancière mentions Olympe de Gouges, a French revolutionary woman, who perfectly embodies dissensus: she both occupied the public space questioning her exclusion, and she showed that "if women are entitled to go to the scaffold, they are entitled to go to the assembly" (ibid, p. 303): Olympe de Gouges demonstrated that she already had the rights which she did not have.
} 
man - are not a political cage; politics consists in the effort of excluded men to demonstrate their attitude to be included.

For his part, Étienne Balibar faces the question of human rights in his discussion of equalibery (Balibar, 2004, 311-322) ${ }^{18}$. According to Balibar, "what is distinctly characteristic of modern citizenship, at least by right or in principle, is the universalization of the status of the citizen" (Balibar, 2004, 312). The most valuable legacy of modern politics is the extensive and intensive universality of citizenship: the right to citizenship is not only universally recognized, but it also allows everybody to partake in politics, that is, it excludes exclusion. If Agamben has stated that the specific performance of human rights - and of sovereign power through them - is the inclusive exclusion of bare life, Balibar replies that human rights do not simply include everybody, but that they exclude exclusion: no one can legitimately be excluded from citizenship. Consequently, the progress of inclusion will one day erase current conditions of exclusion. In Balibar (312)'s words:

"[The status of citizen] ceases to be a privilege and instead comes to be conceived in terms of universal access, or a universal right to politics: a right not only to political rights (a 'right to have rights', as Arendt said), but also to effective political participation. What is at stake in this conception [...] is in the first place an extensive universality - that is, a cosmopolitical horizon, approached in different degrees by various national or federal citizenship, or, better yet, by the articulation of national citizenship and international law. But even more important is what I would call an intensive universality, which gives as support or 'subject' for political participation common humanity, the Gattungwesen or 'species-being' [...], the man without particular qualities (if not without properties). This intensive universality excludes exclusion, forbids the denial of citizenship in the name of determinations of condition, status, or nature" (312).

Specifically, the tension between extensive universality - i.e. universal access to rights - and intensive universality - i.e. each man's inclusion in political activity - is better expressed in the "competition between the notions of fundamental rights [...] and that of popular sovereignty or legislative and constituent 'general will'" (313).

Balibar aims to strengthen this double foundation of western politics, by erasing every residual limitation of citizenship: the only way to actualize intensive and extensive universality is abandoning every limitation to the definition of human beings. According to Balibar, the means for this generalization is the spread of active citizenship, since "man is made by citizenship and not citizenship by man" (321 and Balibar, 2011, 53).

In conclusion, Balibar hopes for a spread of the Rights of Man towards a full universality founded in active citizenship; nonetheless, he relies on the logic of sovereignty of people, according to the democratic principle, for this increase. Both Rancière and Balibar aim for an

\footnotetext{
18 The term "equaliberty" was first coined by Balibar himself; it indicates the inner tension in modern political tradition between equality - i.e. the claim for social rights and political representation - and liberty - i.e. the right to political activity. This tension operates in the contradictory between human rights ("Men are born and remain free and equal in rights") and citizen's rights ("The law is the expression of the general will. All citizens have the right to contribute to it", Balibar, 2014, 44.).
} 
WORLD COMPLEXITY SCIENCE ACADEMY JOURNAL| Vol. 1 Iss. 3, 22 | Winter 2020

enlargement and widening of human rights through citizenship inside a sovereign state, eventually coupling with international institutions.

However, form Arendt's viewpoint what stateless have lost is not only a community: "it is that their membership in a community has been forcefully taken away by the state's insisting on its sovereign right of expulsion through acts of denationalization" (DeGooyer, 2018, 26). Therefore, it is unlikely that the same communities and sovereign states who detracted stateless of rights might ever recognize them again.

Lastly, Rancière and Balibar's answer to the question about the subject of the Rights of Man is: active citizenship enacts human rights, that is Citizen makes Man, and Rights of Man are actually the rights of the citizen.

\section{Arendt on revolution: local Councils and Universal Institutions}

This paper proposes that Arendt's answer to the perplexities of human rights which she had analysed in The Origins of Totalitarianism has to be found in her book about the Revolution, mainly in the fourth chapter entitled Constitutio libertatis (Arendt, 1990, 141-178), as well as in her report in Eichmann (Arendt, 2006).

This hypothesis is supported by the fact that Arendt's analysis of the decline of the nation state had pointed out at the inability of both sovereign nation-state system and its international institutions to guarantee human rights to those who were nothing but men19. Nevertheless - in her essay from 1957 (Arendt, 1968, 81-94) on Jasper's book Origins and Goal of History Arendt highlights a double tension in contemporary citizenship: on one hand "nobody can be a citizen of the world as he is the citizen of his country [...]. Citizen is by definition a citizen among citizens of a country among countries" (81). On the other hand, "Mankind, which for all preceding generations was no more than a concept or an ideal, has become something of an urgent reality" (82): a unified Earth was in the twenties and in the thirties the result of the global imperialism prescribing the nation-state structure everywhere; in the fifties, the globe was unified by the threaten of the atomic weapons (83). Nowadays, in Beck's terms, we live in a global risk society.

While the globe is already unified, each man, people and state should partake in it through its own perspective: "political concepts are based on plurality, diversity, and mutual limitations"

\footnotetext{
${ }^{19}$ This results from the following text: "Humanity, which for the eighteen centuries, in Kantian terminology, was no more than a regulative idea, has today become an inescapable fact. This new situation, in which 'humanity' has in effect assumed the role formerly ascribed to nature or history, would mean in this context that the right to have rights, or the right of every individual to belong to humanity, should be guaranteed by humanity itself. It is by no means certain whether this is possible. For, contrary to the best-intentioned humanitarian attempts to obtain new declarations of human rights from international organizations, it should be understood that this idea transcends the present sphere of international law which still operates in terms of reciprocal agreements and treaties between sovereign states; and, for the time being, a sphere that is above the nations does not exist. Furthermore, this dilemma would by no means be eliminated by the establishment of a 'world government'. Such a world government is indeed within the realm of possibility, but one may suspect that it might differ considerably from the version promoted by idealistic-minded organizations. The crimes against human rights, which have become a speciality of totalitarian regimes, can always be justified by the pretext that right is equivalent to being good or useful for the whole in distinction to its part" (Arendt, 1976, 289-299).
} 
(81). Global unification cannot result from a global sovereign government, nor from keeping alive the sovereign state system. Exposing Jasper's viewpoint on a global organisation, Arendt seems to establish the basis for her following reflection on the federal American government: "the prerequisite for world government in Jasper's opinion is the renunciation of sovereignty for the sake of a world-wide federated political structure" (84).

As previously shown, according to Arendt, the declaration of the Rights of Man had been wasted from its very beginning by the emptiness of "Man": this Man assumed a worldly solidity only by becoming the citizen of a national and sovereign state, or by their arrangement to be the rights of the poor and impotent people. Moving from Arendt's analysis, Agamben proposes a politics beyond human rights (Gündoğdu, 2015, 41) and beyond sovereign biopower: bare life itself should free from sovereign power. Agamben stands on Arendt's statement that "refugees driven from country to country represent the vanguard of their peoples" (Arendt, 2008, 274), for assuming the status of refugee and of bare life as the core of the new political order, with cities becoming the pivot for an articulation and perforation of national territories (Agamben, 2008, 95). However, Agamben drops the last part of Arendt's phrase, where she claims that refugees can be the vanguard of their people "if they keep their identity" (Arendt, 2008, 274): Arendt addresses the entangle between active citizenship, non-sovereign and non-national states, and international institutions, where refugees are forced to station. On the contrary, Rancière and Balibar aim to rehabilitate human rights in the frame of sovereign state, by filling them through active political participation: if, as Arendt notes, man is nothing but the citizen, active citizenship is the only means to becoming men and thus excluding exclusion.

Arendt's position is a little more entangled, since it aims not only to revive active citizenship like in the ancient polis (Arendt, 1998, 25), but also to integrate active political participation with the juridical State as well as with international institutions, as revealed by her report on Eichmann trial. However, the abdication of sovereignty and nationalism is the keystone and the conditio sine qua non for her perspective on the joint of the different levels of power.

The abdication of sovereignty would be impossible without Arendt's redefinition of power which Arendt accomplished in her text about the American revolution. Arendt's idea of power differs profoundly from the current meaning of the term: since the modern age on, power has been tightly tied to violence, sovereignty and abuse. Thus, Agamben's equation between power, sovereignty and violence sticks to the current sense of the term. Arendt's correction of the meaning of power aims to bring to light the concealed founding of the current idea ${ }^{20}$. This hidden foundation is the consent of every citizen: each man supports the political organization which he belongs to by following its orders or acting accordingly to $\mathrm{it}^{21}$, even if he does not swear allegiance to that government, since no man could actually be forced to obey. On the other hand, according to Arendt, "power corresponds to the human ability not just to act but to act in concert" (Arendt, 1972, 142) ${ }^{22}$ : far from indicating the oppressive rule of the leading

\footnotetext{
${ }^{20}$ Ricoeur states that, according to Arendt, power produced by plurality is the forgotten foundation of politics, even when everyone hides consent with obedience (Ricoeur, 1989, 148).

21 "An adult consents when a child obeys. If an adult is said to obey, he actually supports the organization or the authority or the law that claims 'obedience"” (Arendt, 2003, 46).

${ }^{22}$ For the difference between power, violence, strength, force and authority, Arendt, 1972, 142-145; see also Arendt, 1998, 200-201.
} 
person or group, power is the result of pacts and agreements among men, which allow them to act together and enforce the body politic. On the contrary, violence - the favourite means of sovereignty - premises the absence of power, since consent disappeared and agreements founding the community crumbled down: violence is the extreme means to offset the absence of power. It is however destructive and leads to political impasses. Thus, from Arendt's viewpoint, the decrease of sovereignty and of its violent means is the condition for the spread of power: effective and consensual institutions require people's participation and agreements, entangled assemblies and limitations.

As a matter of fact, Arendt's rejection of the State sovereignty records the actual crisis of States since the time period between the two World Wars: as previously mentioned, Europe's failure in managing the question of stateless and minorities witnessed the crumbling foundation of the European political order. Furthermore, the 19th century and its unbridled imperialism had shown that World itself was the horizon of the great worldly powers; the bureaucratic methods ${ }^{23}$ and systematic violence ${ }^{24}$ used in the colonies falsified apodictically the principles of self-determination and sovereignty of all peoples. Well before the rise of totalitarianism, the European worldly order was unstable and unfair.

This crumbling structure is even more fragile nowadays. The sovereign state faces several threats from disproportionate enemies: there are worldly forces, such as globalization (Cavarero, 2002, 519), whose dynamics overcome national borders and overwhelm politically and economically sovereign states. All over the world immigrants move like spectres across seas and lands, trying to force state borders or living invisibly in them. Terrorist organizations (Ibid.) have gained an international stage, while the Covid-19 virus challenges human mobility and state economics in every single country in the world. Finally, ecological crisis silently threatens human existence itself. On the other side, local vindications and territorial forces fight overwhelming events which seem to come from nowhere: many regions in Europe want independence (Catalonia in Spain or the Italian party Lega Nord); in some places these local powers assume a libertarian appearance, like in Kurdistan, where there is a fight against ISIS (Daesh) and a refusal of capitalism, a care for climate crisis, internationalism and the pole reversal between state and local communities (Effenbergen et al., 2017).

The spread of the term global itself, from Caravero's viewpoint (Cavarero, 2002, 523-524), is testament of the changing worldly order, since "global" took the place of words like international and supranational, whose typesetting implies that nation-state is still the cardinal knot of political order. Since global has become the main political scenario, its dialectical pole is no more national, territorial sovereign state, but local: "the global is not opposed to territory but to local" (524).

At the same time, Human Rights still hardly fight for universal recognition. Efforts for finding universal formulation of human rights have been renewing since the France Declaration in 1789 (Arendt, 1976, 272-291), coupling with the creation of new international institution. In 1948 the United Nations released the Universal Declaration of Human Rights, which was followed by the creation of several political institutions aiming at enacting these Declarations

\footnotetext{
23 "Race and Bureaucracy" (Arendt, 1976, 185-221).

${ }^{24}$ Arendt mentions for example the Boers in South Africa (Arendt, 1976, p. 181).
} 
in continents and states ${ }^{25}$. In 1951 the Refugee Convention of Geneva was issued, which also barely faces sovereign states xenophobic politics. From the seventies on, people's care for human rights, and efforts towards internationalization resulted in Amnesty International winning the Nobel Peace Prize (DeGooyer, 2018, 58). Nevertheless, sovereign states still obstruct the application of international declarations; this happens a fortiori where the values founding human rights are not universally recognized.

In this scenario, Arendt's reading on the American Revolution, specifically of the birth of the Federal Constitution, accounts these plural political levels for a profitable interaction, aiming at the abolition of sovereignty in States. The lower level - and yet the most relevant one, in Arendt's view - is one which could be defined as direct democracy, or a Republic, in Arendt's words ${ }^{26}$. Councils express the very essence of politics: they allow each man to act publicly in front of other equal men (Arendt, 1998, 175). This lost treasure (Arendt, 1961, 3 and 1990,216 ) of political tradition glimpsing across European modern history ${ }^{27}$, was a very concrete reality in the pre-revolutionary North America. Pilgrims and colonialists had already given themselves constitutions and rules through reciprocal promises, which became stronger and stronger because of the multiplication of institutions and, finally, because of the foundation of the Federal Constitution itself:

"The astounding fact that the Declaration of independence was preceded, accompanied, and followed by constitution-making in all the thirteen colonies revealed all of a sudden to what an extent an entirely new concept of power and authority, an entirely novel idea of what was of prime importance on the political realm had already developed in the New World [...]. What was lacking in the Old World were the townships of the colonies, and, seen with the eyes of a European observer, the American Revolution broke out, and the doctrine of the sovereignty of the people came out of the townships and took possession of the state. Those who received the power to constitute, to frame constitutions, were duly elected delegates of constituted bodies; they received their authority from below, and when they held fast to the Roman principle that the seat of power lay in the people, they did not think in terms of a fiction and an absolute, the nation above all authority and absolved from all laws, but in terms of a working reality, the organized multitude whose power was exerted in accordance with laws and limited by them. The American revolutionary insistence on the distinction between a republic and a democracy or majority rule hinges on the radical separation of law and power, with clearly recognized different origins, different legitimations, and different spheres of application" (Arendt, 1990, 167).

\footnotetext{
${ }^{25}$ The European enactment of the Declaration was the European Convention of Human Rights, whose juridical institution, the European Court of Human Rights, was founded in 1959; nevertheless, the judgments of this organ are still only advisory. Thus, sovereignty of nation-state still obstructs the enactment of the Conventions. These declarations fail $a$ fortiori where the values they claim are not culturally recognized. On this topic, Arendt points out at the inefficacy of Europe's effort to prescribe its laws all over the world (Arendt, 1968, 81); therefore, she suggests, following Jaspers, a debate about these common values (84-91).

${ }^{26}$ Arendt did not use the term democracy, since the revolutionary tradition has garbled that word in her view (Arendt, 1990, 223).

${ }_{27}$ Arendt mentions the Commune of Paris in 1871, the spontaneous assemblies which rose in Russia in 1905 and the Soviets in 1917, the Bavarian Räterepublik in 1919 and the Hungarian Revolution in 1956 ( Arendt, 1990, 262).
} 
Arendt did not claim that people should rule, but that they should act politically in the frame of the law: law itself is the first limitation to sovereignty as absolute power. Nevertheless, Arendt thought that people's political activity should integrate not only with other councils and townships, but also with higher institutions; to this aim, Arendt refuses the principle of representative democracy, since in this form of government people are not allowed to participate in political life and therefore delegates represent only private groups' interests which Arendt considered highly not political. Arendt aims for "representatives freely chosen by the consent of loving friends and neighbours" (Arendt, 1990, 176), who could limit Councils and are limited by them, but at the same time they strengthen each other. Finally, higher institutions - i.e., the Congress and the Supreme Court - are taken in the same logic of reciprocal limitation and increase of power with each other and with lower institutions. Therefore, the result of the Federal Constitution is the balance between a vertical and horizontal plurality of powers, which dissolves sovereignty ${ }^{28}$ and empowers institutions with consensus.

However, according to Arendt (1972, 231), just after the birth of the Federal Constitution, love for political freedom tragically disappeared for the sake of the durability of the Constitution. Those who came after the Founding Fathers were gifted by their ancestors of a new form of government, but they did not find the space for acting politically, express dissensus and change the constitution itself ${ }^{29}$.

Finally, what is the place of human rights in this new plural structure? While the only future of the State is a federation rooted in active citizenship, Human Rights are still there, witnessing their difference from civic rights: Balibar and Rancière state that the citizen is the concrete form of Man, and that human rights can be guaranteed only by the expansion of citizenship. Arendt $(2006,244)$ - even if she does not restore a discourse on Human Rights, nor on the right to have rights - recognises the need for an international law addressing mankind, mainly to defend the victims of crimes against Humanity. If the "possession paradox" is true, then only the violation of a right reveals it (Donnely, 1985, 13): the rights of man are necessary the Rights of the Victims.

Politics is global, and totalitarianism shew the world a new form of crime, which is still hard to understand juridically and morally:

"The totalitarian attempt at a global conquest and total domination has been the destructive way out of all impasses. Its victory may coincide with the destruction of humanity; whatever it has ruled, it has begun to destroy the essence of man" (Arendt, 1976, VIII).

This paper is not meant to discuss the nature of the crime against humanity; however, Arendt's formulation of the sentence against Eichmann is maybe poor, since it circumscribes the crime against humanity to the destruction of a people's viewpoint on the world:

\footnotetext{
${ }^{28}$ According to Arendt $(1972,100)$, the Federal Constitution lacks the principle of sovereignty - Bodin's Raison $d^{\prime}$ 'État, even if the political practice was introducing it during the second half of the $20^{\text {th }}$ century by the "political question doctrine" by which the Supreme Court gave up the judgment of constitutionality over a government decision.

${ }^{29}$ That is the reason why Arendt $(1972,83-4)$ suggests that civil disobedience should be paradoxically inserted in the Constitution, juridically recognizing the right to break the law in order to manifest dissensus.
} 
"And just as you supported and carried out a policy of not wanting to share the earth with the Jewish people and the people of a number of other nations - as though you and your superiors had any right to determine who should and who should not inhabit the world - we find that no one, that is, no member of the human race, can be expected to want to share the earth with you. This is the reason, and he only reason, you must hang" (Arendt, 2006, 279).

Committing a crime against humanity means - according to Arendt - rejecting to share the globe with other peoples; instead, sharing it means building institutions for making common rules and agreements possible.

However, what Arendt achieved in her report on Eichmann was the need of a discussion about the crime against humanity to be carried by international institutions ${ }^{30}$, and about the competence and legitimacy of these institutions.

Finally, and most importantly, the efficacy of these international institutions presupposes the disposal of the principle of sovereignty, in its bond with territory and nation: the joint of local, state and international bodies on the grounds of reciprocal limitation and strengthen through pacts. Otherwise, the survival of sovereignty risks corrupting every international institution, by making it a global government managing through omnipotent "federated police forces" (Arendt, 1968, 94) with every dissensus, making it a public order question. The other, less dystopic option is that sovereign powers make international institutions a means in their hands, avoiding every serious shared discussion about the status of the Human Rights and of crimes against humanity, while taking advantage of humanitarian policies.

Finally, Arendt's reflection on the Eichmann trial and on Revolution forces to question again: Who is the subject of the Rights of Man? This paper demonstrated that it is not the citizen, and that it negatively relates to the idea of a crime against humanity. Consequently, a new discussion about the Rights of Man is necessary, and even more necessary are international institutions with the competence and authority to recognize and judge them.

\section{References}

Agamben G., 1998, Homo sacer. Sovereign power and bare life, translated by D. Heller-Roazen, Stanford University Press, Stanford; original edition: Homo sacer. Il potere sovrano e la nuda vita, Einaudi, Torino, 1995

\footnotetext{
30 "Among the numerous and highly qualified voices that rose objections to the court in Jerusalem and were in favour of an international tribunal, only one, that of Karl Jaspers, stated clearly and unequivocally [...] that 'the crime against the Jews was also a crime against mankind', and that 'consequently the verdict can be handed down only by a court of justice representing all mankind'. Jaspers proposed that the court in Jerusalem, after hearing the factual evidence, 'waive' the right to pass sentence, declaring itself 'incompetent' to do so, because the legal nature of the crime in question was still open to dispute, as was the subsequent question of who would be competent to pass sentence on a crime which had been committed on government orders" (Arendt, $2006, \mathrm{p}$. 269). Similarly, nowadays the absence of a commonly recognized definition of terrorism allows summary execution of terrorist leaders; for example, some European country are proposing to strike off Kurds from the number of terroristic entities, which they still are for Turkey, USA and Europe itself.
} 
WORLD COMPLEXITY SCIENCE ACADEMY JOURNAL| Vol. 1 Iss. 3, 22 | Winter 2020

Agamben G., 2004, The Open. Man and Animal, translation by D. Attell, Stanford University Press, Stanford; original edition: L'Aperto. L'uomo e l'animale, Bollati Boringhieri, Torino, 2002.

Agamben G., 2008, Beyond Human Rights, in Social Engineering, Open, N. 15.

Arendt H., 1961, Between Past and Future. Six Exercises in Political Thought, The Viking, New York.

Arendt H., 1968, Karl Jaspers, Citizen of the World, in Men in Dark Times, Harcourt Brace \& Company, New York.

Arendt H., 1972, Crisis of the Republic, Harcourt Brace \& Company, San Diego/ London/ New York, pp. 103-184.

Arendt H., 1976, The Origins of Totalitarianism, Harocurt Brace Jovanovich, San Diego, New York, London, p. 290.

Arendt H., 1990, On Revolution, Penguin Books, London.

Arendt H., 1993, Was ist Politik? Fragmente aus dem Nachlaß, Hereausgegeben von U. Ludz, Piper, München/Berlin.

Arendt H., 1998 The Human Condition, with an introduction by Margaret Canovan, The University of Chicago Press.

Arendt H., 2003, Personal Responsibility under a Dictatorship, in Responsibility and Judgment, edited by J. Kohn, Schoken Books, New York, pp. 17-48.

Arendt H., 2006, Eichmann in Jerusalem. A Report on the Banality of Evil, introduction by A. Elon, Penguin, London.

Arendt H., 2008, We Refugees, in J. Kohn and R. H. Feldman (edited by), Jewish Writings, Schocken Books, New York, 264-274.

Balibar É., 2004, Is a Philosophy of Human Civic Rights Possible? New Reflections on Equaliberty, The South Atlantic Quarterly 103, 2/3, Spring/Summer.

Balibar É., 2011, Réponse à la question de Jean-Luc Nancy: Qui vient après le sujet?, en Citoyen Sujet et autres essais d'anthropologie philosophique, Presses Universitaire de France, Paris.

Balibar É, 2014, Equaliberty. Political Essays, translated by J. Ingram, Duke University Press, Durham; original edition: La proposition de l'égaliberté, Presses universitaire de France, Paris, 2010

Benhabib S., 2003, The Reluctant Modernism of Hannah Arendt, Roman \& Littlefield Publisher, Lanham/ Boulder/ New York/ Toronto/ Oxford.

Cavarero A. 2002, Politicizing Theory, Political Theory, Vol. 30 No 4, August, 506-532.

DeGooyer S., Hunt A., Maxwell L., Moyn S., Taylor A., 2018, The Right to have Rights, Verso, London/Brooklyn.

Donnelly J., 1985, Concept of Human Rights, St. Martin's Press, New York.

Effenbergen W., Flach A., Plumba K., Schaber P., Schelm L., 2017, Konkrete Utopie, Unrast Verlag, Münster.

Foucault M., 1976, Histoire de la sexualité I. La volonté de savoir, Gallimard, Paris.

Foucault M., 1994, Le problème des réfugiés est un présage de la grande migration du XXI ${ }^{e}$ siècle, in Dits et écrits, Gallimard, Paris, vol. III, pp. 798-800 
Greblo E., 2018, Umanità di confine, Aut-aut, 378, pp. 64-88

Gündoğdu A., 2015, Rightlessness in an age of rights: Hannah Arendt and the contemporary struggle of migrants, Oxford University Press, Oxford.

Ojakangas M., 2005, Impossible dialogue on Biopower. Agamben and Foucault, Foucault Studies, No 2, pp. 5-28, May.

Rancière J., 2004, Who is the Subject of the Rights of Man? South Atlantic Quarterly, Spring/Summer, 103 (2-3); 297-310.

Ricoeur P., 1989 Pouvoir et violence, en M. Abensour (édité par), Ontologie et Politique. Actes du colloque Hannah Arendt, Tierce, Paris.

Snoek A., 2010, Agamben's Foucault: an overview, Foucault Studies, No 10, pp. 44-67, November.

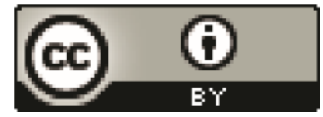

This article is distributed under the terms of the Creative Commons Attribution 4.0 License (https://creativecommons. org/licenses/by/4.0/) which permits any use, reproduction and distribution of the work without further permission provided the original work is attributed as specified on the WCSA Journal by World Complexity Science Academy (https://www.wcsaglobal.org/ethics-policy/). 